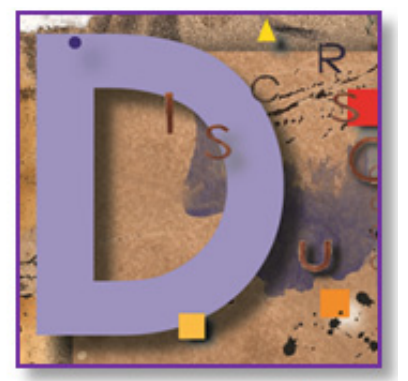

\title{
HEGEMONIA E INSURGÊNCIA NO DISCURSO CINEMATOGRÁFICO: O PENSAMENTO SOCIAL CRÍTICO
}

\author{
Dina Maria Martins Ferreira (UECE) ${ }^{1}$ \\ Tibério Caminha Rocha (UECE) ${ }^{2}$
}

DISCURSOS CONTEMPORÄNEOS

EM

ESTUDO

ISSN $2237-7247$

Este estudo tem por objetivo fomentar discussões sobre a importância do discurso cinematográfico como prática social, haja vista os efeitos de sentido construídos na sociedade. Nossa argumentação visa à desmistificação da supervalorização estética da cinematografia em prol de sua avaliação crítica, já que não podemos negar o seu papel de (re)produção de representações da sociedade, que, muitas vezes, naturalizam interpretações de mundo; marcas ideológicas, partícipes do construto de sentidos, são, muitas vezes, veículos alegóricos que camuflam as representações sociais que ali se manifestam, sejam em seu roteiro, sejam em sua mise-en-scène. Nosso objeto em foco, o filme Clube da Luta é, aqui, apresentado como um veículo de contestação do modelo de cultura do consumo socialmente construído. A narrativa fílmica é analisada a partir da hipótese de que a ficção está ao alcance da representação do cotidiano vivido e, como tal, uma prática social, enquanto construção social da realidade. A trilha retórica e argumentativa se organiza em torno de pressupostos conceituais de Adorno e Horkheimer (cf. ADORNO, 1987) sobre a indústria cultural, aliados à visão crítica de Thompson (1995) a respeito dos meios de comunicação de massa; teia em que se articulam os estudos da significação discursiva e situacional propostos pela pragmática contemporânea.

Palavras-chave: indústria cultural; prática social; ideologia; representação social.

\footnotetext{
${ }^{1}$ Pós-Doutorada pela Université Paris V, Sorbonne e pela Unicamp; membro da ABRALIN, ALED, GT ANPOLL e CEAQ (Centre d'Études sur les Actuels et le Quotidient, da Université Paris V, Sorbonne); desenvolve estudos na área de de Análise do Discurso Crítica, em Pragmática e Linguística Aplicada; autora do livro Políticas em Linguagem: perspectivas pragmáticas (2006), Não pense, veja, o espetáculo da linguagem no palco do Fome Zero (2006), Discurso Feminino e Identidade Social (2009, 2a. ed.), Imagens: o que fazem e significam (2010), entre outros; dinaferreira@terra.com.br

2 Mestre pelo Programa de Pós-Graduação em Linguística Aplicada /UECE; desenvolve pesquisas na área da Análise do Discurso Crítica e da Pragmática, com ênfase em representação social e ideologias; tiberiocaminha@ gmail.com
} 


\section{Considerações iniciais}

A partir de 1923, com a publicação do Manifesto das Sete Artes ${ }^{3}$ pelo teórico e crítico de cinema italiano Ricciotto Canudo, o cinema passou a ser designado de "a sétima arte", por reunir em um todo os elementos básicos que constituem o corpo de cada uma das artes precursoras, que se sujeitam a seguinte classificação: 1. Música (som), 2. Dança (movimento), 3. Pintura (cor), 4. Escultura (volume), 5. Teatro (representação) e 6. Literatura (palavra) (GIMELLO-MESPLOMB, 2011). O poder de historiar e registrar acontecimentos também caracteriza o cinema como uma forma de arte, tornando-o parte irredutível do contexto social, pois é aí que o conceito de arte é redefinido como um modo particular de prática ao lado da produção, consumo, linguagem etc. A arte é, então, destituída de sua posição em um patamar privilegiado, prerrogativa concedida anteriormente às classes abastadas, e restituída em um lugar de cultura comum, ordinária, por intercambiar significados comuns, que rodeiam os corredores do cotidiano da vida ordinária.

Dirigida por David Fincher em 1999, a adaptação para as telas do best-seller Clube da Luta (1996), de Chuck Palahniuk, torna evidente a possibilidade de a cinematografia funcionar como veículo de contestação de padrões preestabelecidos e de emulação de um pensamento social crítico. A narrativa do filme Clube da Luta gira em torno de um trabalhador assalariado anônimo de classe média incapaz de adequar-se tanto ao estilo americano de vida quanto à cultura do capitalismo. Na tentativa de expurgar o desconforto que sente em relação ao mundo, o protagonista decide experimentar a vida fora dos padrões considerados pelo senso comum como normais, fundando um clube privado de lutas em parceria com o vendedor de sabonetes anti-social Tyler Durden. Através de personagens complexos e de um roteiro com conteúdo irônico e mordaz de difícil digestão, o filme instiga a audiência a pensar sobre o modelo de sociedade consumista em que vivemos.

\section{Percurso histórico-conceitual}

Estabelecendo uma correspondência baseada em graus de semelhança, diferença e relação entre o cinema e as outras artes, a cinematografia destaca-se por ter a capacidade discursiva sincrética de agregar esferas codificadoras diversas, tais como imagem em movimento (daí a categorização cinema, em grego skiné), fala (e legendas, quando é o caso), som, tanto na esfera temporal quanto na espacial - cuja forma de representação, muitas vezes, reflete-se na experiência cotidiana. Porém, segundo Vernet (1995), a grandeza avaliativa de tais paralelismos está na dialética entre o realismo cinematográfico e o realismo de outros tantos modos de representação (outras artes), e não apenas em relação ao mundo real - aí a abordagem valorativa de uma sétima arte atribuída à indústria cinematográfica.

\footnotetext{
${ }^{3}$ Manifesto das Sete Artes e Estética da Sétima Arte de Canudo ocorreu em 1912, mas só foi publicado em 1923, no entanto, Canudo já tinha publicado em Paris, 1911, o artigo "La naissance d'un sixième art. Essai sur le cinématographe".
} 
Com o advento do Centro de Estudos Culturais Britânicos ${ }^{4}$, em Birmingham, os estudos culturais, até então focados nas condições de que significados de âmbito social são produzidos pela cultura, ganham novo fôlego, porquanto introduz no campo dos Estudos Culturais a teoria do cinema: demonstrou-se que esta tinha interseções com metodologias procedidas de outras disciplinas, tais como a semiótica, a psicanálise, a linguística e a antropologia, ampliando, assim, o campo de pesquisa a respeito dos processos das práticas culturais. O próprio conceito de cultura foi redefinido "como o processo que constrói o modo de vida de uma sociedade: seus sistemas para produzir significado, sentido ou consciência, especialmente aqueles sistemas e meios de representação que dão às imagens sua significação cultural" (TURNER, 1997, p. 48).

E sendo o cinema considerado um 'produto's cultural, pode ser analisado como uma estrutura complexa, cuja composição excede os limites impostos pela própria forma fílmica, pondo sua construção ao alcance da representação - "o processo social de fazer com que imagens, sons, signos, signifiquem algo" (Ibidem, idem). Neste sentido, a indústria cinematográfica passa a ser considerada como um exercício de influências em instâncias sociais, uma vez que toda representação é uma prática de significação que (re)produz cultura (HALL, 1997). O conteúdo sociocultural da cinematografia, articulado por meio de um sistema de códigos semióticos e/ ou linguísticos, passa então a dar vazão a questionamentos voltados à representação, à (des) construção de identidades, à produção ideológica do consumo e outros tantos .

No que tange a questões referentes à produção do consumo no discurso cinematográfico, tal produção atua em um nível ideológico, inconsciente ou conscientemente, pois as práticas sociais são motivadas por um tipo específico de interesse e subjetivação, ou seja, a relação entre texto (discurso cinematográfico, no caso), sociedade e cultura está imbricada de considerações ideológicas. Para que entendamos a prática cultural como efetiva em uma determinada sociedade, é necessário também observá-la atuando em círculos invisíveis, naturalizados e 'pseudo' desinteressados, o que nos remete de novo ao modus operandi da ideologia. Daí a dificuldade de dissociar cultura de ideologia, pois, mesmo que a esta não assuma forma material 'mostrada', seus efeitos são perceptíveis nas manifestações culturais.

Circunscrevendo o cinema ao conceito de meio de comunicação de massa, no livro Ideologia e Cultura Moderna (1995), Thompson chama a atenção para o sentido do termo 'massa'. Segundo o autor,

(...) o termo "massa" não deve ser tomado em termos estritamente quantitativos; o ponto importante sobre comunicação de massa não é que um determinado número ou proporção de pessoas receba os produtos, mas

\footnotetext{
4 Em 1964, pesquisadores britânicos oficializam a criação do Centre for Contemporary Cultural Studies (hoje conhecido como a disciplina Estudos Culturais), na Universidade de Birmingham, para investigar questões culturais sob a perspectiva histórica, criando um novo campo de pesquisa sobre os fenômenos comunicacionais em sociedade. No entanto, já havia trabalhos precursores, tais como E.P.Thompson (1963) The Making for the English Working Class. Outro autor destacado desse centro é Stuart Hall (Representation: cultural representations and signifying practices. London/Thousand Oaks/New Delhi: Sage, 1997), que procurou mostrar a importância do estudo da ideologia para se compreender a estrutura social de poder, sustentando que a comunicação social era produtora e reprodutora de ideologias.

${ }^{5}$ Usamos o termo produto entre aspas simples, para chamar a atenção que a noção de cultura não se estabelece como um produto fixo e acabado em si mesmo, e sim por uma contínua prática social.
} 
que os produtos estão, em princípio, disponíveis a uma pluralidade de receptores (THOMPSON, 1995, p. 287).

No senso comum, ao nos referirmos às grandes audiências através do termo 'massa', poder-se-ia estar sugerindo que o todo-massa seja constituído por aglomerações de indivíduos passivos e indiferentes, ou seja, como se coletividade tivesse uma acepção fundamentalista, senão essencialista e fixa. No entanto, Thompson (Ibidem) nos alerta sobre o fato de quão ilusória é tal interpretação, pois ela cria a falsa consciência de que, mesmo que as mensagens construídas/transmitidas pela indústria do cinema sejam acessíveis a um público relativamente amplo, não existem audiências, sejam quais forem, particulares ou massivas, pequenas ou especializadas, que não ocupem seus lugares em seus contextos sócio-históricos. O dito todo-massa não anula a subjetividade da significação nem a capacidade de interação, ou seja, o público interpreta sentidos e intenções construídas no discurso fílmico, em um processo ativo: subjetiva a significação, integrando-a a outras esferas de atividade do cotidiano vivido. Ilustrando algumas interações observadas pelos pesquisadores: no filme Clube da Luta, espectadores ao final do filme comentam: Que filme ruim, violento! Por que tanto sangue?; no filme Beleza Americana ${ }^{6}$, alguns sentem mal-estar, uns conscientemente por se refletirem em um cotidiano de aparência burguesa, outros apenas clamam por uma diversão mais leve, tipo filme de amor com happy end. Conscientemente ou não, a interação com o cotidiano e suas representações aí se presentificam.

\section{Perspectivas da indústria cultural cinematográfica}

Adorno e Horkheimer (Cf. ADORNO, 1987) ${ }^{7}$ reprovam as nomenclaturas "cultura de massa" ou "cultura popular", pois, ainda que habituais, tais expressões reforçam a crença de que tais tipos de cultura tratam-se de manifestação da arte popular, emergindo 'naturalmente' das próprias massas. A expressão "indústria cultural" foi, justamente, trazida à luz por tais autores na intenção de não só evitar a ambiguidade de sentido que permeia as expressões mencionadas anteriormente, mas também de intervir na acepção de que o discurso fílmico, por exemplo, seja um produto audiovisual adaptado ao processo que eles chamaram de "mercantilização de formas culturais" por uma empresa capitalista. Em uma sociedade de consumo, em que o homem utiliza para satisfação das próprias necessidades e desejos tanto bens materiais quanto signos, a unicidade da arte é banalizada pela demanda dos tempos modernos e a cultura é transformada também em mercadoria (ANDRADE, 2000).

Uma vez que a grande arte caiu sob o peso da linguagem do comércio, da produção e do consumo e sua razão vinculada à consumação das massas, a indústria cinematográfica transformou a esfera cultural, consequentemente, em um campo de lutas hegemônicas. É

6 Beleza Americana, filme dirigido por Sam Mendes, de 1999, premiado com Oscar, justamente pela intenção crítica de uma representação da sociedade americana burguesa.

7 Referimo-nos a ambos os pensadores Horkheimer e Adorno, mesmo que a referência bibliográfica esteja em publicação de autoria de Adorno, porquanto o texto trabalha o tempo todo com o pensamento de ambos. Daí quando do uso de ambos os nomes se colocar na referência o "cf." 
importante enfatizar que o sistema ideológico em que a cultura se insere não é estável, ou seja, grupos, gêneros e classes competem entre si, motivados por interesses contrários, pela dominância ininterruptamente - daí podermos entrever o processos de resistência. Assim, através da reprodução constante de fórmulas prescritivas, o cinema passou, também, a servir de instrumento de dominação, que age por meio do convencimento, alienando o pensamento crítico e autônomo das massas (ADORNO, 1987). De acordo com o raciocínio de Adorno e Horkheimer (Cf. ADORNO, 1987) determinados gêneros cinematográficos exerceriam a função de simular à realidade nas telas, reduzindo a nada a importância do papel da memória social do homem, e de favorecer aos interesses das classes dominantes, impedindo a urgência de um momento de transição em seu meio "pela difusão de informação e de conselhos, e de padrões aliviadores de tensão" (Ibidem, p. 291).

Hipoteticamente, a repetição exagerada de um modelo estandardizado de roteiro não se trataria, então, de uma questão de falta de criatividade, mas sim de uma tentativa de manutenção da ordem social através de um 'produto' cultural, e consequente empobrecimento de sentidos, o que faria o público espectador digerir apenas o montante de informação que a indústria cultural disponibilizaria. Ainda que houvesse espaço para transformações e inovações no cinema, estas teriam que se encaixar em um jogo de intenções, tendo sempre em vista as necessidades do produtor e não a do consumidor.

A hipótese de que a indústria cinematográfica induz à apatia social e sustenta as relações de dominação exemplifica o poder de persuasão e dissuasão do discurso cinematográfico, mas se nos ativermos apenas a esta visão simplista e conservadora apresentada por Adorno e Horkheimer (Cf. ADORNO, 1987), a gama de possibilidades que tal meio oferece ao homem ficaria bastante restringida. O cinema é, também, um lugar para a insurgência de um pensamento social crítico.

A interpretação desses pensadores sobre a natureza da indústria cultural nos serve de advertência para uma faceta dos meios de comunicação de massa que as próprias massas ignoram. No entanto, a suposição de Thompson (1995), de que há audiências específicas constituídas por receptores ativos, aponta para a ampliação deste conceito em relação ao papel do consumidor crítico e autônomo do produto midiático. A questão da ideologia ressurge não apenas sob o caráter de "deformadora da realidade", mas também como "forma autônoma, aliada a práticas sociais concretas - simbólicas e imaginárias - que podem transformar indivíduos em sujeitos ativos e participantes dos processos sociais, culturais e políticos" (BORELLI, 1995, p. 75).

Os processos ideológicos atrelam-se ao skiné, imagem em movimento, construindo significações e subjetivações através de um sistema de representações, dando vazão à nova abordagem dos estudos críticos do cinema sugerida por Vernet (1995), visto que a união entre ideologia e cinema põe em evidência a existência de relações entre o discurso cinematográfico e a sociedade e entre registro e acontecimento, assim como introduz uma possibilidade de rupturas com a tradição sociocultural "imposta" ao público receptor. 
O discurso cinematográfico apresenta dimensão ideológica à medida que se estabelece uma correlação entre as impressões deixadas no roteiro e na mise-en-scène com as próprias condições socioculturais de produção do filme. Tal dimensão ideológica se insere, de fato, na formação identitária do espectador de forma explícita ou subliminar, porquanto os modos de construção dos sentidos do discurso sincrético (no caso o cinético) - linguagem sonora, gestual e corporal e representação visual - interagem com o indivíduo espectador. Interpretamos, assim, que as condições de produção de sentidos refletem o próprio contexto sociocultural situado; o cinema, sendo uma prática social com construções ideológicas, constrói sua reflexibilidade cultural por intermédio das relações entre o seu produtor e a sociedade, ambos no universo do situatedness.

\section{Clube da Luta: representação e ideologia}

A adaptação do best-seller Clube da Luta (1996), de Palahniuk, para as telas reproduz a visão de mundo particular do diretor estadunidense Fincher (1999). Essa percepção de mundo é a interpretação da sociedade pelo indivíduo, mas ao fazermos tal afirmação tornase necessário esclarecermos que a experiência e as percepções individuais são orientadas pelo modo de vida e pelas práticas coletivas; em outras palavras, a representação parte do imaginário social para alojar-se na consciência individual (MOSCOVICI, 2010). Por tratar-se de uma construção social, e como tal não apenas individual, pois a visão de mundo retratada em Clube da Luta traça correlações de elementos tanto da realidade do diretor quanto do espectador - representação, regulação, produção, identidade, consumo etc. -, o sentido do filme só pode ser determinado através da análise dos significados partilhados entre o produtor e o consumidor.

Nesses termos, a mensagem transmitida pelo filme Clube da Luta, que serve de ponte de informações entre a produção e a massa consumidora, é articulada dentro de um sistema de trocas simbólicas, onde é determinante que o autor e o receptor tenham categorias de percepção e avaliação de mundo análogas para que sejam efetivas (BOURDIEU, 1996). O que é importante aqui é a permuta de visões de mundo, conhecimentos e crenças comuns, entre pessoas inscritas em um mesmo contexto histórico-social, mesmo que a comunicação estabelecida entre o cinema e o público espectador não obedeça aos parâmetros de uma situação dialógica de conversação usual.

É essencial tomarmos em consideração a linha de pensamento traçada anteriormente para a compreensão do fato de que a construção do personagem principal, como um narrador anônimo, dá margem para que a questão da representação social (re)produzida no filme seja apreciada a partir de outros pontos de vista, não apenas como um ideário inerente de Fincher.

A falta de uma identidade específica torna implícita a relação existente entre o protagonista do Clube da Luta e o indivíduo que pertence às 'massas', ou seja, o anti-herói da trama pode servir de referência para qualquer sujeito que veja, sinta ou julgue o mundo a partir do mesmo contexto situacional. 
Esse ‘qualquer sujeito', o protagonista em um contexto situacional, é interpretado pelo ator Edward Norton,

[...] um trabalhador assalariado anônimo em uma companhia de automóveis de classe média. De acordo com as regras de conduta de seu meio social, o protagonista veste-se de um modo tradicional, senão formal,que se adéqua ao vestuário habitual de escritório. Uma vez que o estilo de vida do Narrador [representação individual/modo de identificar] não pode contrastar com seu ambiente de trabalho [representação coletiva/ identificação relacional ${ }^{8}$ ] - o que configuraria uma contradição social -, o personagem mora em um condomínio residencial no centro da cidade, de cômodos com utensílios e móveis condizentes com seu poder aquisitivo, ou capital econômico (ROCHA, 2013, p. 92).

Inferimos, então, que a intenção do diretor seria de que o personagem representasse nas telas de cinema a figura do homem comum da classe média americana cujo estilo de vida não o dissociasse do coletivo. Embora a perspectiva em foco seja a de Fincher - pois não é nossa proposta negar a autoria -, a problemática da construção identitária do protagonista apresenta-se propositalmente ambígua em termos de 'quem' Norton está representando no discurso cinematográfico - se é uma instituição, o espectador ou o diretor.

Uma vez que a falta de clareza na mensagem da narrativa fílmica é intencional, podemos concluir que a responsabilidade pela interpretação de sua significação cai sobre o público receptor. Seguindo a conjunção lógica de argumentos de Thompson (1995), ainda que Clube

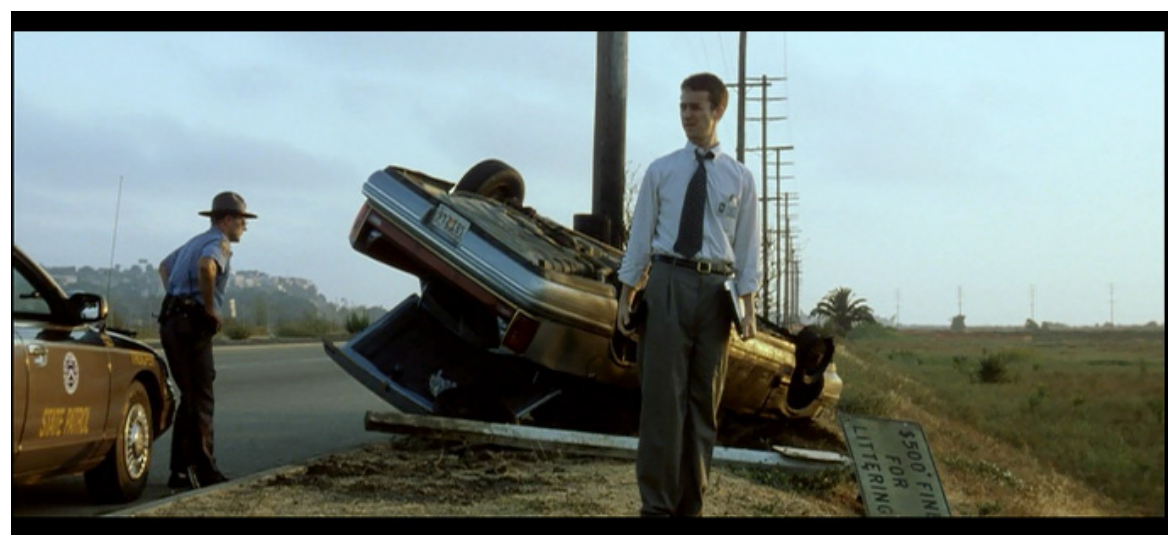

da Luta seja um produto da indústria cultural disponível para o consumo das grandes massas, o filme encontrou o seu público nas audiências pequenas e especializadas, que conseguiram se 'identificar' com a representação que se vê nas telas e, consequentemente, capturar o sentido do filme - crítica à sociedade de consumo.

\footnotetext{
8 Segundo a definição de Ramalho e Resende, "a identificação relacional diz respeito à identificação de atores sociais em textos em termos das relações pessoais, de parentesco ou de trabalho que têm entre si. Esse tipo de identificação é 'relacional' no sentido de que depende das relações sociais e das posições em que os atores ocupam” (2011, p. 131).
} 
Convém, aqui, lembrarmos de que Clube da Luta é um filme de difícil compreensão para o espectador que tem o hábito de consumir as produções típicas do cinema de Hollywood, - representação de sistemas de previsibilidades da realidade -, devido ao conteúdo intelectual elaborado implícito de sua narrativa, que corrói progressivamente paradigmas naturalizados. De acordo com Kellner (2001, p. 135),

\begin{abstract}
Deve-se notar, porém, que o cinema de Hollywood enfrenta severas limitações no grau com que pode preconizar posições críticas e radicais em relação à sociedade. Trata-se de um empreendimento comercial que não deseja ofender as tendências dominantes com visões radicais, tentando, portanto, conter suas representações de classe, sexo, raça e sociedade dentro de fronteiras preestabelecidas.
\end{abstract}

Por abordar temas tabus que transgridem regras sociais básicas, como violência, terrorismo, sexo e drogas, e por questionar um sistema de valores já cristalizado na cultura, a prática do consumo, o filme em si selecionou o seu próprio público. Esta hipótese é confirmada pelo status de cult movie que Clube da Luta alcançou no ano de seu lançamento em DVD, independente da fama ou do reconhecimento no circuito comercial. Turner $(1997$, p. 100) nos dá uma ideia do processo de identificação do público com o filme:

Ao contrário do que muitas pessoas pensam, o público não comparece aos cinemas iludidos por campanhas publicitárias falsas ou enganosas. Uma frase geralmente usada pelos produtores refere-se ao filme "que encontra o seu público", e esta é a descrição mais precisa do que realmente acontece.

A justificativa de Fincher para a violência explícita em profusão no corpo do filme é a tentativa de alertar as grandes audiências para os perigos de um sistema social capitalista e consumista que insiste em impor, de maneira direta ou indireta, normas de conduta e estilos de vida para que o homem se encaixe no modelo de sociedade em vigor. Tal violência é uma metáfora, senão uma alegoria, que o diretor utiliza para ilustrar a negação e a insatisfação do indivíduo contemporâneo em relação à cultura do consumo propagada pelos próprios meios de comunicação de massa.

Entendemos o discurso fílmico Clube da Luta como uma alegoria, pois se trada de um tecido retórico discursivo que constrói uma dialética entre o sentido 'literal' e o 'figurado', dialética de virtualizações de sentido. Melhor explicando, o que chamamos de sentido 'literal' seria o aspecto classificatório primeiro, explícito, de ser o filme apenas uma narrativa de violência (para alguns, até de pertencer à categoria de um filme de ação), mas que, no entanto, aí não se fixa, pois implicita e projeta um sentido mais profundo (chamado de figurado) que nos empurra para a representação de uma sociedade corrosiva e corroída pela necessidade do consumo. Ratificando, o sentido (a) 'literal' estaria para um filme interpretado apenas como um espelho da violência, que remete ao sentido (b) o figurado - discurso crítico contra 
a hegemonia de uma sociedade de consumo. Mas ao também designarmos o filme como metafórico, não estamos jogando fora sua tessitura alegórica, pois poderíamos afirmar que um discurso alegórico é alimentado por metáforas. Ou seja, sendo o filme uma alegoria, por sua própria natureza, 'con-figura' e 're-con-figura' - se mostra (figura) junto (com) a algo e de novo (re) se mostra (figura) junto (com) a algo -, e sendo o filme constituído por metáforas, o mesmo movimento complexo se dá na constituição metafórica que continuamente alarga e expande sentidos ${ }^{9}$. Ambas tessituras se retro-alimentam na construção de uma crítica social anti-hegemônica: se a violência é a corporificação das lutas e conflitos presentes no imaginário social, o Clube da Luta é emancipação do, resistência ao e insurgência contra o mal-estar da sociedade.

Segundo Turner (1997, p.76), a função da narrativa pode ser tomada em consideração apresentando duas possibilidades distintas ao homem: "A primeira é que a narrativa pode ser uma propriedade da mente humana, como a linguagem; a segunda é que a narrativa talvez desempenhe uma função social essencial que a torna indispensável para as comunidades humanas". Ainda, de acordo com a argumentação desse autor, o papel da narrativa do filme Clube da Luta é resolver simbolicamente a questão da inclusão e exclusão social determinada pela prática do consumo, que não pode ser resolvida no mundo real, pois é tida na consciência das massas como consequência natural da existência do homem - uma problemática social menosprezada por já estar interiorizada, senão naturalizada, no conceito de cultura. Em vista disto, o discurso cinematográfico em foco procura dar vazão a uma nova interpretação de sentido do mundo através de uma representação social crítica.

Como se pode notar, não seria correto resumirmos o conteúdo do Clube da Luta como somente um filme que faz apologia à violência, existe muito mais de forma subjacente. A intenção do filme contradiz a hipótese sugerida por Adorno e Horkheimer (Cf. ADORNO, 1987) de que o papel da indústria cultural seria apenas o de proporcionar entretenimento ao público que consome o produto midiático, alienando a consciência das massas "sem oferecer ao consumidor as condições necessárias ao pensamento crítico" (ANDRADE, 2000, p. 36), e de que trabalharia a favor da manutenção de relações de dominação. Ao contrário, a proposta do filme Clube da Luta é fomentar a discussão a respeito da inadequação do ser humano frente à nova realidade chamada pós-moderna, mas que estimula sentimentos primitivos, como o do individualismo e o da agressividade.

Com efeito, o tema central do romance escrito por Palahniuk (1996), e posteriormente, adaptado para as telas por Fincher (1999), faz parte de uma série de fatores que reforçam, formam ou alteram as representações em atividade no seio da sociedade. As transformações que tais representações sofrem, motivadas pela fluidez do panorama social, afetam diretamente às esferas de atividade humana, incluindo o campo cultural. Nesses termos, podemos inferir que é a instabilidade das representações sociais que confere o caráter temporal da indústria cultural, indispensável à sua própria sobrevivência, reiterando continuamente a união entre representação e cultura.

\footnotetext{
${ }^{9}$ Apontamos a diferença entre alegoria e metáfora: a metáfora não se constitui por comparação e sim por equivalência, enquanto a alegoria permite a comparação entre sentidos: sentido literal (a) que dá lugar ao sentido figurado (b); mas ambas se ancoram no sentido 'figurado'.
} 
No contexto do filme Clube da Luta, a representação social adquire o status de representação ideológica (FISKE apud CURRAN; GUREVITCH, 1996), pois os equipamentos de cinema, por exemplo, a câmara de vídeo, excedem a função básica de registrar e historiar a realidade. O discurso cinematográfico não pode ser reduzido a códigos linguísticos e semióticos da realidade, porquanto (re)produz uma representação da visão de mundo (e a de Fincher) que é indissociável de intenções ideológicas. Neste aspecto, os sentidos em atividade na película do filme, que fazem relação com a representação da sociedade capitalista e com a crítica à cultura do consumo, não são reificados pelo poder inato da indústria cinematográfica de reproduzir a experiência e o conhecimento cotidianos, pois as marcas ideológicas explícitas e implícitas não desaparecem de suas representações, mesmo que sublimine o seu caráter crítico através da alegoria. Logo, nos posicionamos a favor da afirmação de Soares (2007), quando o autor diz que a representação que se vê nas telas de cinema não é da realidade, mas da própria ideologia.

\section{Considerações Finais}

A partir dessa reflexão, pusemos em destaque alguns aspectos que consideramos indispensáveis para uma compreensão da prática social que reside no discurso fílmico, estabelecendo uma analogia entre a concepção de meio de comunicação de massa de Thompson (1995) e a interpretação de indústria cultural de Adorno e Horkheimer (cf. ADORNO, 1987).

Visamos esclarecer que forma da narrativa do filme Clube da Luta desempenha uma função no interior da própria sociedade que o produziu, pondo-se em resistência à hegemonia conservadora, assim como à sua política e à sua cultura; e por meio de cenários estratégicos reivindica a não-manutenção de relações de dominação ideológica (GRAMSCI, 1971). No entanto, para alguns desavisados, a aparente manutenção das relações de dominação se legitima pela então nomeada prática discursiva dos meios de comunicação de massa como subterfúgios para a própria sustentação. Tal argumentação acomoda o nosso objeto em foco dentro do conceito de filme de cunho liberal formado por Kellner (2001, p. 136):

[...] filmes liberais podem ser interpretados como contestações à hegemonia conservadora, e não apenas como pusilânimes variações da mesma ideologia dominante. Dessa perspectiva contextualista, a crítica da ideologia implica uma análise ideológica no contexto da teoria social. A interpretação política dos filmes, portanto, pode propiciar a compreensão não só dos modos como o filme reproduz as lutas sociais existentes na sociedade americana contemporânea, mas também da dinâmica social e política da época.

Essa teia argumentativa objetivou desmitificar a crença popular de que o produto final da indústria cinematográfica tem, tão somente, em vista o preenchimento da lacuna de tempo ocioso do dia a dia vivido. As grandes audiências podem até conferir, inconscientemente, 
uma neutralidade de intenções no que é apreciado nas telas de cinema, mas, sob um viés crítico, ratificamos que não há atos desinteressados na produção cinematográfica, uma vez que a própria falta de intencionalidade de certos gêneros de cinema mascara uma manifestação ideológica proposital. Debord (1997, p. 24) ilustra nossa colocação ao explicar como se dá o processo de dissimulação da ideologia por meio do contexto midiático:

A alienação do espectador em favor do objeto contemplado (o que resulta de sua própria atividade inconsciente) se expressa assim: quanto mais ele contempla, menos vive; quanto mais aceita reconhecer-se nas imagens dominantes da necessidade, menos compreende sua própria existência e seu próprio desejo.

Mesmo que aceitemos a existência de um público-massa, ancorado no espaço da alienação, há sempre espectadores críticos e ativos à espreita, capturando o conteúdo ideológico das representações sociais (re)produzidas em películas fílmicas, como no caso da Clube da Luta, que dão margem à quebra de valores instituídos por uma classe dominante, valores estes inerentes tanto à sociedade quanto à condição de existência do homem. Seria imprudente de nossa parte, aqui, afirmarmos que o território em que se assenta o discurso cinematográfico já foi resolvido e explorado in totum, pois os fenômenos sociais não são estáticos, mas sim processos em contínua equivalência com suas representações (re)produzidas em cena.

\section{Referências}

ADORNO, Theodor W. A indústria cultural. (Trad. Amélia Cohn) In: COHN (Org.), Gabriel. Comunicação e Indústria Cultural. 5. ed. São Paulo, T. A. Queiroz, 1987.

ANDRADE, Roberta Manuela Barros de. O fim do mundo: imaginário e teledramaturgia. São Paulo, Annablume; Fortaleza: Secretaria da Cultura e Desporto do Governo do Estado do Ceará, 2000.

BORELLI, Silvia Helena Simões. Gêneros ficcionais: materialidade, cotidiano, imaginário. In: SOUSA (Org.), Mauro Wilton de. Sujeito, o lado oculto do receptor. (Trad. Sílvia Cristina Dotta e Kiel Pimenta). São Paulo, Brasiliense, 1995.

BOURDIEU, Pierre. Razões Práticas. Sobre a teoria da ação. (Trad. Mariza Corrêa). São Paulo, Papirus, 1996.

DEBORD, Guy. A Sociedade do espetáculo. (Trad. Estela dos Santos Abreu). Rio de Janeiro, Contraponto, 1997.

FISKE, John. Post-modernism and television. In: CURRAN, James; GUREVITCH, Michael (eds). Mass media and society. London/Sidney/Aukland, Arnold, 1996. 
GIMELLO-MESPLOMB, Frédéric. Manifeste dês sept arts. França, Université de Metz. Disponível em:<http://fgimello.free.fr/enseignements/metz/textes_theoriques/canudo.htm.> Acesso em: 28 abr. 2012.

GRAMSCI, Antonio. Selections from the prison notebooks. (Trad. para o inglês Farouk Abdel Wahab de Zayni Barakatfoi). New York, International publishers, 1971.

HALL, Stuart. Representation: cultural representations and signifying practices. London/Thousand Oaks/New Delhi, Sage, 1997.

KELLNER, Douglas. A cultura da mídia - Estudos Culturais: identidade e política entre o moderno e o pós-moderno. (Trad. Ivone Castilho Benedetti). São Paulo, EDUSC, 2001.

MOSCOVICI, Serge. Representações Sociais: investigações em psicologia social. (Trad. Pedrinho A. Guareschi). 7. ed. Rio de Janeiro, Vozes, 2010.

PALAHNIUK, Chuck. Fight Club. Great Britain, Vintage Books, 1996.

ROCHA, Tibério Caminha. 2013. 144 páginas. Dissertação em Mestrado em Linguística Aplicada, Universidade Estadual do Ceará.

SOARES, Murilo Cesar. Representações da cultura mediática: para a crítica de um conceito primordial. Anais Encontro da Compós, 16, 2007, Curitiba, UTP, 2007.

THOMPSON, John B. Ideologia e cultura moderna: teoria social crítica na era dos meios de comunicação de massa. (Trad. Grupo de Estudos sobre Ideologia, Comunicação e Representações Sociais da PUCRS). Petrópolis, RJ, Vozes, 1995 [2002].

TURNER, Graeme. Cinema como prática social. (Trad. Mauro Silva). São Paulo, Summus, 1997.

VERNET, Marc. Cinema e narração. In: AUMONT, Jacques et al. A sstética do filme. (Trad. Marina Appenzeller). Campinas, SP, Papirus, 1995.

\section{Filmografia}

Beleza Americana (American Beauty). Filme de Sam Mendes (1999). Roteiro: Alan Ball. Produção: Dream Works Pictures, 1999, 122 minutos.

Clube da Luta (Fight Club), direção de David Fincher (1999), roteiro de Jim Uhls, produção da 20th Century Fox, 1999, 139 minutos; adaptação da obra de Chuck Palahniuk Fight Club. 